Article

\title{
Neuronal Nitric Oxide Synthase Induction in the Antitumorigenic and Neurotoxic Effects of 2-Methoxyestradiol
}

\author{
Magdalena Gorska ${ }^{1, *}$, Alicja Kuban-Jankowska ${ }^{1}$, Michal Aleksander Zmijewski ${ }^{2}$, \\ Monika Gorzynik ${ }^{1}$, Michal Szkatula ${ }^{1}$ and Michal Wozniak ${ }^{1}$
}

1 Department of Medical Chemistry, Medical University of Gdansk, Gdansk 80-211, Poland; E-Mails: alakuban@interia.pl (A.K.-J.); monika.gorzynik@urz.pl (M.G.); mszkatula@gumed.edu.pl (M.S.); mwozniak@gumed.edu.pl (M.W.)

2 Department of Histology, Medical University of Gdansk, Gdansk 80-211, Poland; E-Mail: mzmijewski@gumed.edu.pl

* Author to whom correspondence should be addressed; E-Mail: m.gorska@gumed.edu.pl; Tel.: +48-349-14-50; Fax: +48-349-14-56.

Received: 3 June 2014; in revised form: 8 August 2014 / Accepted: 18 August 2014 / Published: 28 August 2014

\begin{abstract}
Objective: 2-Methoxyestradiol, one of the natural $17 \beta$-estradiol derivatives, is a novel, potent anticancer agent currently being evaluated in advanced phases of clinical trials. The main goal of the study was to investigate the anticancer activity of 2-methoxy-estradiol towards osteosarcoma cells and its possible neurodegenerative effects. We used an experimental model of neurotoxicity and anticancer activity of the physiological agent, 2-methoxyestradiol. Thus, we used highly metastatic osteosarcoma 143B and mouse immortalized hippocampal HT22 cell lines. The cells were treated with pharmacological $(1 \mu \mathrm{M}, 10 \mu \mathrm{M})$ concentrations of 2-methoxyestradiol. Experimental: Neuronal nitric oxide synthase and 3-nitrotyrosine protein levels were determined by western blotting. Cell viability and induction of cell death were measured by MTT and PI/Annexin V staining and a DNA fragmentation ELISA kit, respectively. Intracellular levels of nitric oxide were determined by flow cytometry. Results: Here we demonstrated that the signaling pathways of neurodegenerative diseases and cancer may overlap. We presented evidence that 2-methoxyestradiol, in contrast to $17 \beta$-estradiol, specifically affects neuronal nitric oxide synthase and augments 3-nitrotyrosine level leading to osteosarcoma and immortalized hippocampal cell death. Conclusions: We report the dual facets of 2-methoxyestradiol, that causes cancer cell death, but on the other hand may play a key role as a neurotoxin.
\end{abstract}


Keywords: osteosarcoma; hippocampus; cancer; neurodegenerative disease; 2-methoxyestradiol; neuronal nitric oxide synthase; 3-nitrotyrosine

\section{Introduction}

Osteosarcoma (OS) is one of the most malignant bone tumors of childhood and adolescence. Despite remarkable improvements in OS therapy implemented in the last few decades, there has been no significant progress since 1970 when series of clinical trials were launched at the Memorial Sloan-Kettering Hospital and neoadjuvant therapy was introduced to treatment. Then the 5-year survival rate reached approx. 70\% [1-5]. The difficulties in effective treatment of OS are associated with its metastatic potential and chemoresistance, thus the searchfor novel, potent anticancer drugs is a scientific task of the highest priority. A great number of studies indicate that carcinogenesis and angiogenesis can be influenced by $17 \beta$-estradiol metabolites [6,7]. 2-Methoxyestradiol (2-ME), one of the natural $17 \beta$-estradiol derivatives, is a novel potentially active anticancer agent [8-11]. 2-ME is active after oral administration and in pharmacological, nontoxic doses affects cancer cell growth both in vivo and in vitro, as well as leading to inhibition of metastatic processes (breast cancer, pancreas cancer, Ewing sarcoma, osteosarcoma) [12-15]. 2-ME (branded as Panzem) is currently being evaluated in ongoing advanced phases of clinical trials in patients with breast cancer, ovarian cancer and prostate cancer or multiple myeloma [8-19]. 2-ME is well tolerated by patients. The adverse reactions of 2-ME are mild and usually involve nausea, vomiting, diarrhea, flushing and headaches [8-11,16-19]. According to Sutherland et al. 2-ME inhibits cell proliferation at threshold concentrations of $0.1-0.3 \mu \mathrm{M}$, reaching its maximum effect at 10-20 $\mu \mathrm{M}$ [20]. Interestingly, normal cells are more resistant to the proapoptotic properties of 2-ME [21,22]. Thus, 2-ME was demonstrated as a relatively safe anticancer agent. Nonetheless, some adverse drug reactions like neurotoxic effects are observed only after long-term administration. Interestingly, a recent study suggested that the molecular pathways of neurodegeneration and cancer may overlap [23]. Several neurodegeneration-causing factors like PARK2 parkin, and PARK5 have been recently been evidenced to be involved in cancer development by playing an important role as regulators of cell cycle [23,24]. In the same context, $\alpha$ - and $\beta$-synucleins may play an important role in cancer pathogenesis, regulation and tumor differentiation, including osteosarcoma [25,26]. Furthermore, it was also demonstrated that selectively nitrated $\alpha$-synuclein is directly associated with nitro-oxidative stress-induced damage and progression of neurodegenerative diseases [26]. Reactive nitrogen species (RNS) play an important role in mediating cell signaling pathways, but their increased concentration leads to nitro-oxidative stress resulting in cell cycle arrest or cell death. Nitric oxide is synthetized by the action of nitric oxide synthases (NOSs), a group of hemoproteins that catalyze oxidation of L-arginine to citrulline releasing a molecule of nitric(II) oxide (NO) [27]. Three isoforms of NOS can be distinguished: nNOS (neuronal nitric oxide synthase) found mainly in neurons, iNOS (inducible nitric oxide synthase) induced by many stimuli like stress or inflammation in different kinds of cells and tissues, and eNOS (endothelial nitric oxide synthase) expressed mainly in endothelial cells [27]. Although nitric oxide is not highly reactive, it may easily react with oxygen radicals to generate highly damaging RNS like peroxynitrite 
or nitrogen dioxide. 3-Nitrotyrosine (3-NT) formed in the reaction of nitrating oxidants with protein tyrosine residues or free tyrosine is a fingerprint of RNS [28]. Due to that fact 3-NT is an indicator of nitro-oxidative stress under pathophysiological conditions. Interestingly, increased levels of nitrated proteins and 3-NT have been associated with a variety of neurodegenerative diseases like Parkinson's disease (PD) [29]. Although 3-NT is considered as a biological marker of RNS, it has been also recently referred to as a neurotoxin [30,31]. However, the molecular mechanism of 3-NT-induced apoptosis still needs to be elucidated.

Due to the fact that glutamergic system and NMDA receptor subunits (NR1, NR2A, NR2B, NR2D) were identified in OS cells [32,33], the main objective of the present study was to determine a plausible link between the molecular mechanisms of neurodegenerative diseases and cancer. For this purpose we used highly metastatic human osteosarcoma 143B cell lines as a model of cancer. Moreover, a mouse immortalized hippocampal HT22 cell line was employed in order to evaluate the neurotoxicity of the compound [34-37]. Herein, we evidenced that 2-methoxyestradiol (2-ME), a physiological derivative of $17 \beta$-estradiol (E2), may induce OS 143B and neuronal HT22 cell death via induction of nitro-oxidative stress.

\section{Results and Discussion}

The interesting notion of the existence of an overlap between neurodegenerative diseases and cancer has been recently demonstrated [23]. Furthermore, it has been suggested that neurodegenerative diseases, mainly Parkinson's disease, and tumors are linked by a negative interaction [23]. Interestingly, this connection concerns not only CNS tumors, but also peripheral ones.

\subsection{Anticancer Effects of 2-ME}

\subsubsection{Antiproliferative Properties of 2-ME}

The original viewpoint on E2 metabolites as being biologically inactive excretion products has been rejected by numerous research findings $[7,13,14]$. Preclinical research suggests a wide spectrum of possible anticancer mechanisms of action of 2-ME that seem to be directly associated with the inhibition of angiogenesis and induction of apoptosis in tumorous and proliferating cells [7,13,14]. The first goal of the study was to determine the antiproliferative effects of 2-ME treatment towards cancer OS and immortalized hippocampal cells. 143B and HT22 cells were treated with a series of dilutions $(0.8-50 \mu \mathrm{M})$ of 2-ME for $24 \mathrm{~h}$. Subsequently, the inhibition of cell growth was observed by means of an MTT-assay. As presented in Figure 1, 2-ME effectively inhibited OS and hippocampal cell growth in a concentration-dependent manner. Viability of 143B cells was significantly diminished from $81 \%$ to $31 \%$ in the presence of $2-\mathrm{ME}(0.8-50 \mu \mathrm{M})$ as compared to control (c) (Figure 1A). As presented in Figure 1B, E2 did not exert any statistically significant antiproliferative effect on OS cells. Proliferation of immortalized hippocampal HT22 cells was inhibited from $92 \%$ to $60 \%$ in the presence of 2-ME $(0.8-50 \mu \mathrm{M})$ as compared to control (c) (Figure 1C). 
Figure 1. Impact of treatment with 2-ME and E2 on OS cell death. $(\mathbf{A}, \mathbf{B})$ Inhibition of cell viability by 2-ME and E2; (C) Inhibition of cell viability HT22 cells by 2-ME. OS 143B and immortalized hippocampal HT22 cells were treated with a series of dilutions $(0.8-50 \mu \mathrm{M})$ of 2-ME or E2. The cell proliferation was determined by MTT assay. 2-ME inhibited 143B cell proliferation in contrast to E2. Data are presented as the mean \pm SE values form at least three independent experiments. Data were analyzed performing One-way ANOVA combined with Dunnett's Multiple Comparison Test; * $p<0.01$ versus control (c).
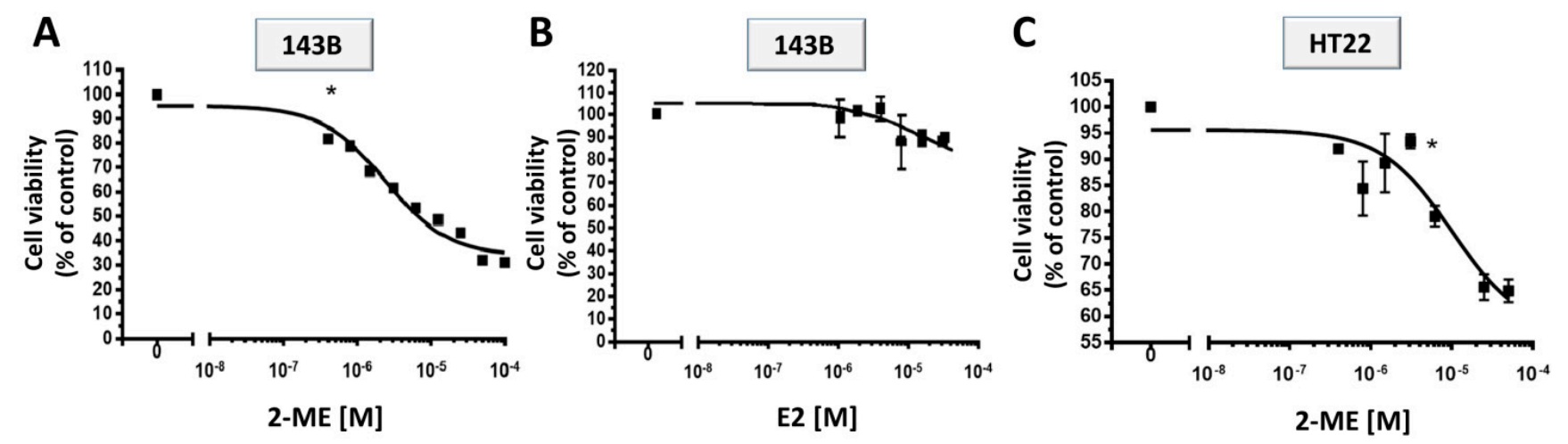

\subsubsection{Effect of 2-ME and E2 on Induction of Cell Death in OS 143B}

The next goal of the study was to determine the induction of cell death in OS and HT22 cells by 2-ME. 143B cells were treated with 2-ME or E2 at concentrations of $1 \mu \mathrm{M}$ and $10 \mu \mathrm{M}$ for $8 \mathrm{~h}$ and $24 \mathrm{~h}$ (Figure 2A-C) to determine the proapoptotic properties of 2-ME. Percent of apoptotic cells after $24 \mathrm{~h}$ incubation with $1 \mu \mathrm{M} 2-\mathrm{ME}$ was statistically elevated up to $10 \%$, while it dramatically increased to $36.3 \% \pm 3.5 \%$ after $24 \mathrm{~h}$ treatment with $10 \mu \mathrm{M} 2-\mathrm{ME}$ (Figure $2 \mathrm{~A}$ ). The level of necrotic cells detected after $24 \mathrm{~h}$ incubation of OS cells with $1 \mu \mathrm{M}, 10 \mu \mathrm{M} 2-\mathrm{ME}$ was equal to $12.3 \% \pm 1.5 \%$ and $26.2 \% \pm 4 \%$, respectively (Figure 2B). E2 induced apoptosis ( $6 \%$ of apoptotic cells) only when used at the concentration of $10 \mu \mathrm{M}$, whereas $1 \mu \mathrm{M}$ E2 did not affect the induction of OS cell death (Figure 2C). Morphological changes characteristic of apoptosis (from irregular shape into a rounded shape) were observed after $8 \mathrm{~h}$ of treatment with 2-ME, while after $8 \mathrm{~h}$ of incubation with E2 we did not notice perturbed cell morphology (Figure 2E). Additionally, we observed a massive induction of cell death after $24 \mathrm{~h}$ treatment of immortalized hippocampal HT22 cells with 2-ME (1 $\mu \mathrm{M}, 10 \mu \mathrm{M}$, Figure 2D). The obtained data suggest that 2-ME exerts both anticancer and neurotoxic effects at pharmacological concentrations. Though, normal cells are thought to be more resistant to proapoptotic properties of 2-ME [21,22], we demonstrated that toxic effect of 2-ME may be dependent on cellular context. Our results support data obtained by the Picazo research group that indicated the neurotoxicity of the agent [38]. Though, 2-ME is well tolerated by patients and the adverse reactions of 2-ME are mild and usually involve nausea, vomiting, diarrhea, flashing, headache [8-11,16-19], we suggest possible long-term side effects of the agent such as memory disorders or depression. 
Figure 2. Impact of treatment with 2-ME on hippocampal cell death. (A-C) Induction of cell death by 2-ME and E2 in OS cells. 143B osteosarcoma cells were treated with vehiculum (c), 2-ME (1 $\mu \mathrm{M}, 10 \mu \mathrm{M})$ or E2 $(1 \mu \mathrm{M}, 10 \mu \mathrm{M})$ for $24 \mathrm{~h}$; (D) Induction of cell death by 2-ME in immortalized hippocampal cells. HT22 cells were treated with solvent (c), 2-ME $(1 \mu \mathrm{M}, 10 \mu \mathrm{M})$ for $24 \mathrm{~h}$. The cells were harvested and the percentage of apoptotic and necrotic cells was determined by PI-Annexin staining. Values are the mean $\pm \mathrm{SE}$ of three independent experiments $(\mathrm{N}=6$ replicate cultures). Data were analyzed performing Student's $t$ tests. $* p<0.1, * * p<0.01, * * * p<0.001, * * * * p<0.0001$ versus control (c); (E) Morphological changes (a-c) and Hoechst 33.258 staining (d-f) observed in control (c); (a), (d), $1 \mu \mathrm{M}$ 2-ME; (b), (e), $1 \mu \mathrm{M} \mathrm{E2;} \mathrm{(c),} \mathrm{(f),} 8 \mathrm{~h}$ treated cells. A representative experiment out of three performed is shown.

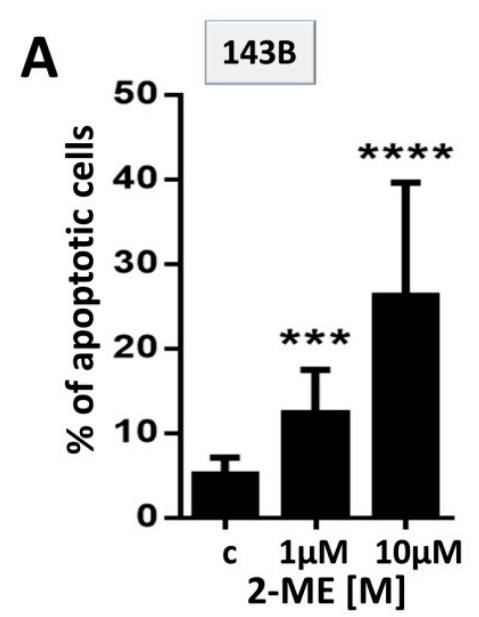

D

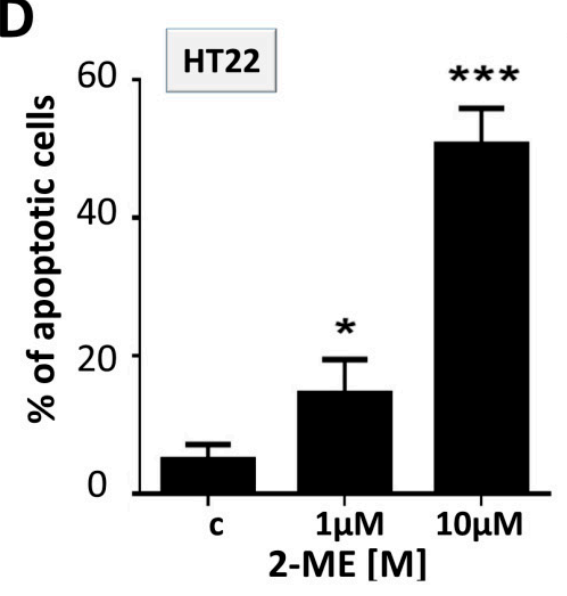

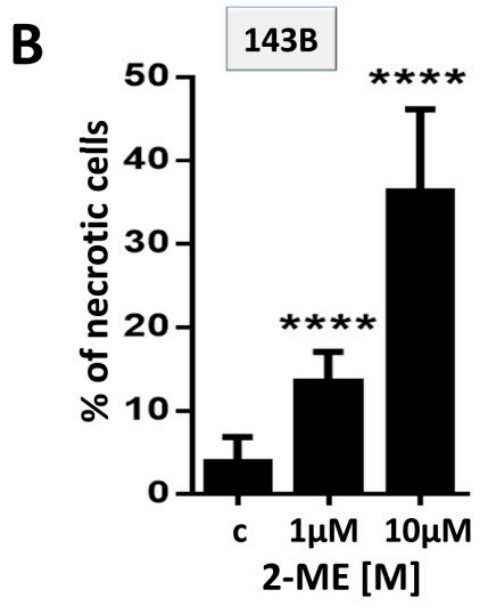

$\mathbf{E}$
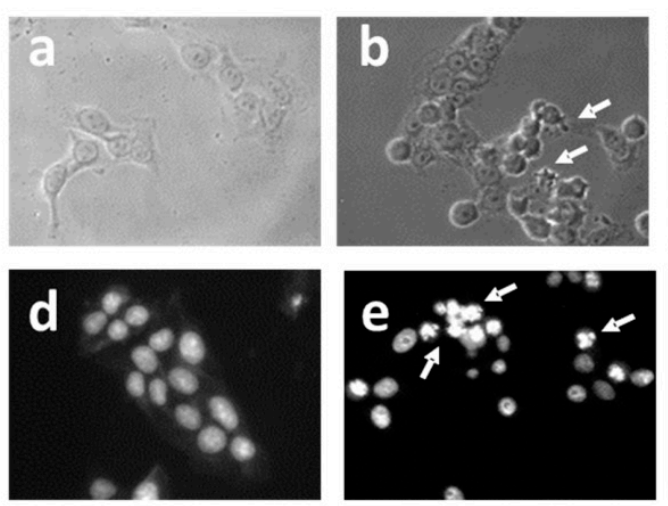

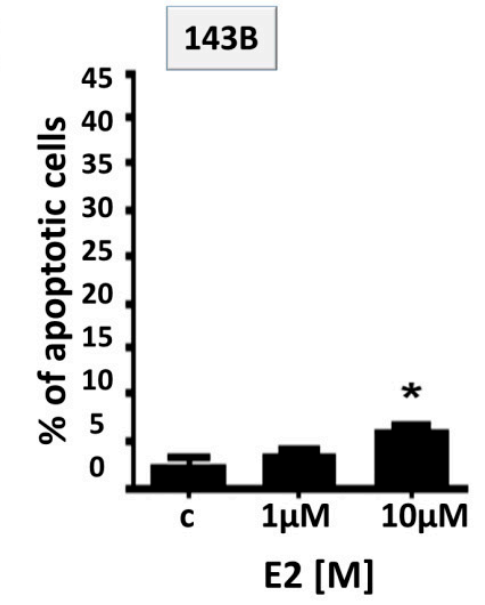

E2 [M]
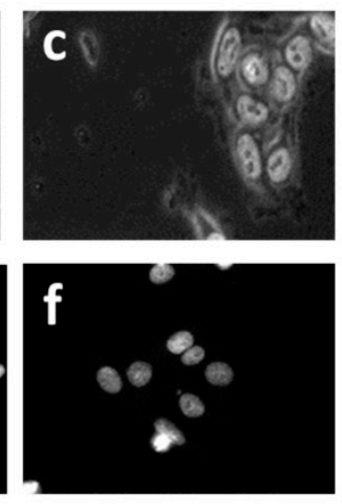

\subsection{Neuronal-Type Signaling in OS Cells-nNOS as Molecular Target of 2-ME}

\subsubsection{Impact of 2-ME on nNOS and 3-NT Protein Levels}

Next, we revealed that molecular target for 2-ME in OS and immortalized hippocampal cells is a neuronal isoform of nitric oxide synthase (nNOS). In vivo studies revealed glutamate receptor activity in tissues such as bone, and NMDA receptor subunits were identified in OS MG63 cells [32,33]. Herein, we have evidenced, to our knowledge for the first time, neuronal-like signaling in non-neuronal highly metastatic human OS 143B cells. Moreover, while nNOS has been believed so far to be only 
a constitutive isoform of the NOS enzyme, we are presenting evidence of its inducible character [39]. 2-ME used at concentration of $1 \mu \mathrm{M}$ selectively increased nNOS protein levels in a time-dependent manner. The level of enzyme was elevated after $1 \mathrm{~h}$ incubation with $1 \mu \mathrm{M}$ 2-ME (2.2-fold as compared to control (c)) with a maximal 3.3-fold increased peak after $4 \mathrm{~h}$ what was maintained till $8 \mathrm{~h}$ of incubation with stimulus (Figure 3A-C). Additionally, E2 lowered the protein level of nNOS in OS cells as compared to 2-ME (Figure 3B). Moreover, the induction of neuronal isoform of NOS by 2-ME seems to be isoform- specific, as 2-ME did not affect eNOS and iNOS protein levels (Figure 4).

Figure 3. 2-ME increased nNOS and 3-NT protein level in OS $143 \mathrm{~B}$ and hippocampal HT22 cells. (A) Time-dependent induction of protein level of nNOS by treatment of OS 143B cells with $1 \mu \mathrm{M}$ 2-ME; (B) 2-ME $(1 \mu \mathrm{M}, 10 \mu \mathrm{M})$ upregulated nNOS protein after $1 \mathrm{~h}$ incubation of OS 143B cells. Treatment of OS 143B cells with E2 $(1 \mu \mathrm{M}, 10 \mu \mathrm{M})$ for $1 \mathrm{~h}$ decreased the enzyme protein level; (C,D) 2-ME $(1 \mu \mathrm{M}, 10 \mu \mathrm{M})$ upregulated nNOS protein after $8 \mathrm{~h}$ of incubation of OS 143B and immortalized hippocampal HT22 cells; (E,F) 2-ME $(1 \mu \mathrm{M}, 10 \mu \mathrm{M})$ increased level of $3-\mathrm{NT}$ in OS cells. HT22 cells are characterized by constitutive high level of 3-NT.
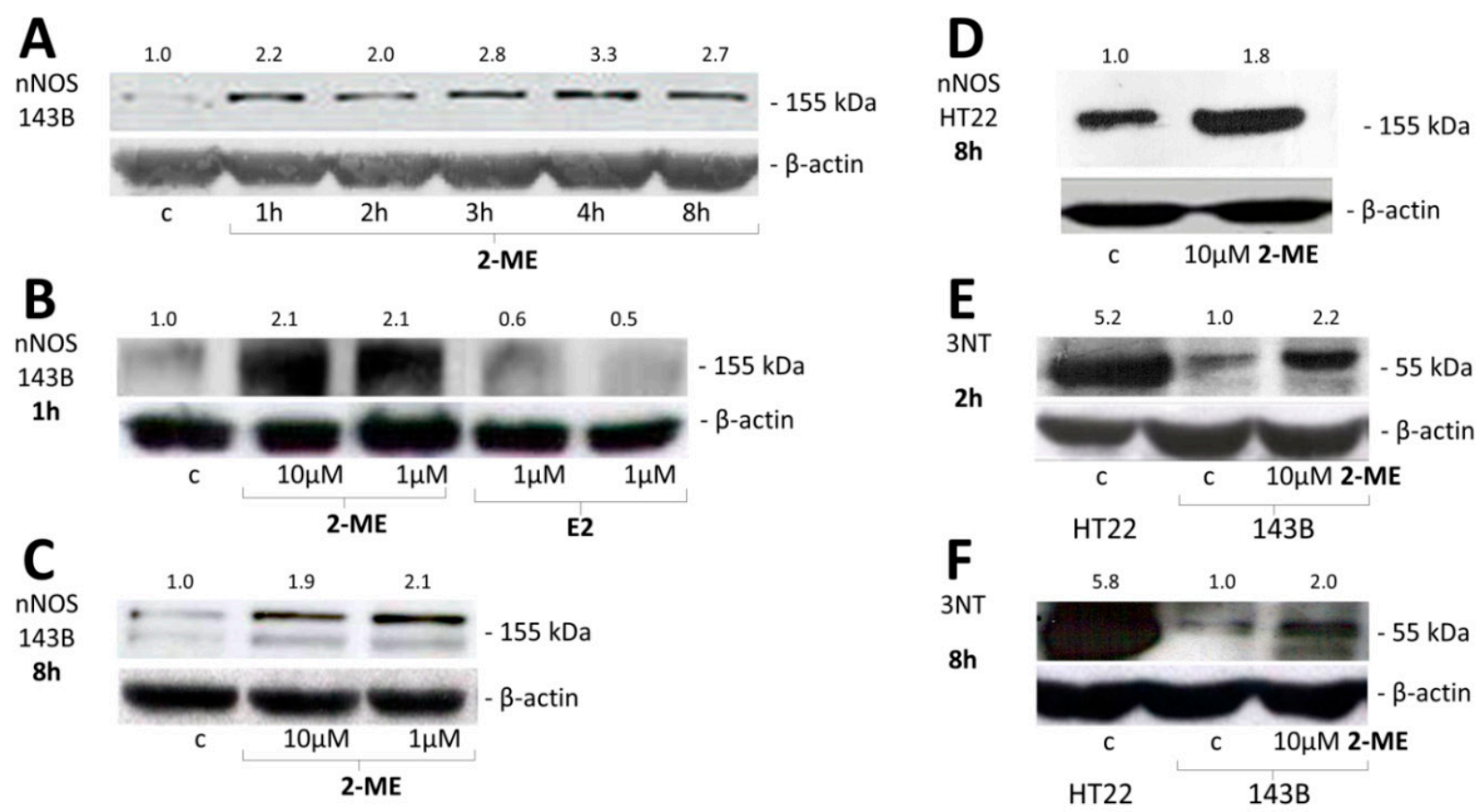

Interestingly, the mode of action of 2-ME is specific not only for cancer OS cells, but also hippocampal cells. 2-ME also increased nNOS protein levels in HT22 cells characterized by constitutive enzyme expression (Figure 3D). The obtained data suggest that nNOS should be also considered as inducible isoform of NOS regulated by 2-ME. In fact, Tsukamoto and co-workers reported that 2-ME increased NOS and linked the production of NO with enhanced apoptosis of endothelial cells [40]. Interestingly enough, levels of nNOS were also elevated by 2-ME in HT22 cells what was correlated with enhanced neuronal cell death after $24 \mathrm{~h}$ treatment with 2-ME (Figure 2). The neurotoxic effects of 2-ME have been previously demonstrated by Picazo et al. and may explain plausible side effects like memory disorders of 2-ME treated patients. The Picazo research group 
noticed that a number of neurons in the hilus of the dentate gyrus of ovariectomized rats were killed by 2-ME [38].

Figure 4. 2-ME does not affect eNOS (A) and iNOS (B) protein level in OS 143B cells. 143B OS cells were treated with vehicle (c) or 2-ME $(10 \mu \mathrm{M})$ for $8 \mathrm{~h}$; The levels of eNOS (A), iNOS (B) protein were determined by immunofluorescence. Cell nuclei are shown in blue while NOSs immunoreactivity is seen in green. Merged images of both were also presented. Each experiment was performed at least three times. The representative data are shown. Original magnification is 40 .

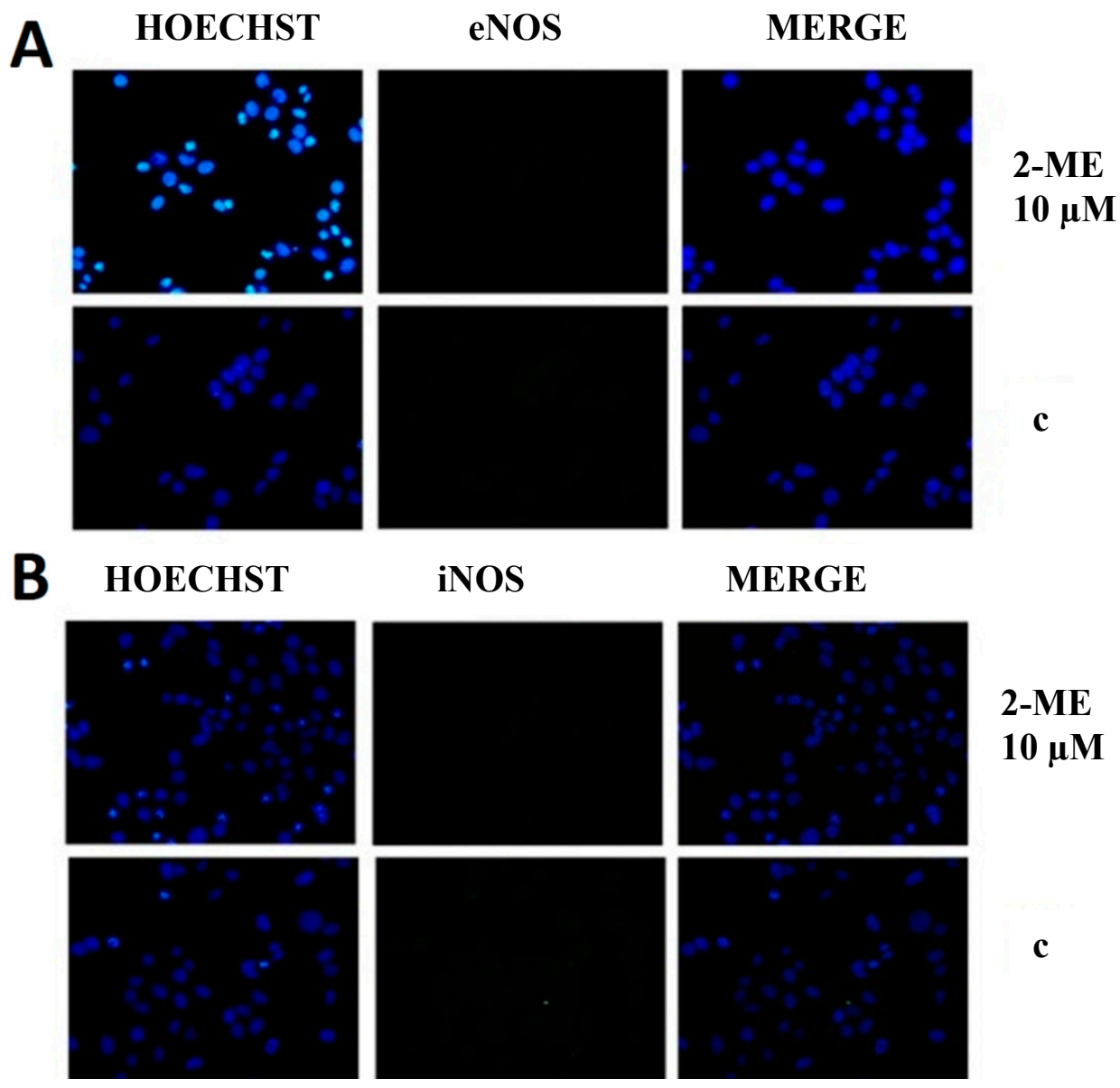

\subsection{2. nNOS Is Engaged in 2-ME Induced Cell Death}

In order to confirm that nNOS participates in the cell killing mechanism of 2-ME in the OS cell death model used in our studies we used $N^{\omega}$-Nitroarginine-2,4-L-diaminobutyric amide di(trifluoroacetate) salt (L-NDBA) that selectively blocks NO production in the cells by inhibition of nNOS. OS 143B cells were pretreated for $1 \mathrm{~h}$ with $10 \mu \mathrm{M}$ L-NDBA and subsequently, treated with $1 \mu \mathrm{M} 2-\mathrm{ME}$ in a time-dependent manner. Cell viability was then determined by means of a MTT assay. Pretreatment of 143B cells with L-NDBA significantly increased the mean survival of the cells in 2-ME-treated cultures by $18 \%$ or $31 \%$, after $16 \mathrm{~h}$ or $24 \mathrm{~h}$ of incubation, respectively (Figure $5 \mathrm{~A}$ ). Next, an enzyme-linked immunosorbent assay (ELISA) was performed for the quantitative determination of cytoplasmic histone-DNA fragments. As shown in Figure 5B, pretreatment of the OS cells with the nNOS inhibitor 
significantly decreased 2-ME-induced apoptosis. The extent of apoptosis observed in the cell cultures $1 \mathrm{~h}$ pretreated with $10 \mu \mathrm{M}$ L-NDBA decreased by approximately $25 \%$ after $16 \mathrm{~h}$ and approx. $36 \%$ after $24 \mathrm{~h}$, as compared to the cells treated with 2-ME alone (Figure 5B). In our studies, both the MTT viability assay and the assessment of DNA fragmentation, revealed that pretreatment with L-NDBA at the concentration of $10 \mu \mathrm{M}$ for $1 \mathrm{~h}$ only partially protected the cells against 2-ME-induced cytotoxicity. These data strongly suggest the vital involvement of nNOS in the 2-ME proapoptotic signalling pathway.

Figure 5. Significance of nNOS in 2-ME-induced apoptosis. (A) Cell viability assay (MTT) revealing the statistically significant influence of pretreatment with $10 \mu \mathrm{M}$ L-NDBA for $1 \mathrm{~h}$ on inhibition of OS 143B cell growth after $16 \mathrm{~h}$ of $1 \mu \mathrm{M}$ 2-ME stimulation. The data are presented as a percentage of control (c); (B) Pretreatment with $10 \mu \mathrm{M}$ L-NDBA for $1 \mathrm{~h}$ significantly decreased the accumulation of oligonucleosomes in the cellular lysates of OS 143B treated with 2-ME. Statistically significant differences were noted after $16 \mathrm{~h}$ of incubation with 2-ME. The results are given as percentage of the control (c); (C) Level of intracellular nitric oxide in 143B cells incubated with $1 \mu \mathrm{M}$ 2-ME. 143B cells were incubated in a time dependent manner with $1 \mu \mathrm{M}$ 2-ME. Afterwards, intracellular level of nitric oxide was determined with usage of specific detector 4,5-diaminofluorescein diacetate (DAF-2DA) by means of flow cytometry. 2-ME statistically significant increased level of nitric oxide in a time dependent manner with maximal peak at $2 \mathrm{~h}$ of incubation.
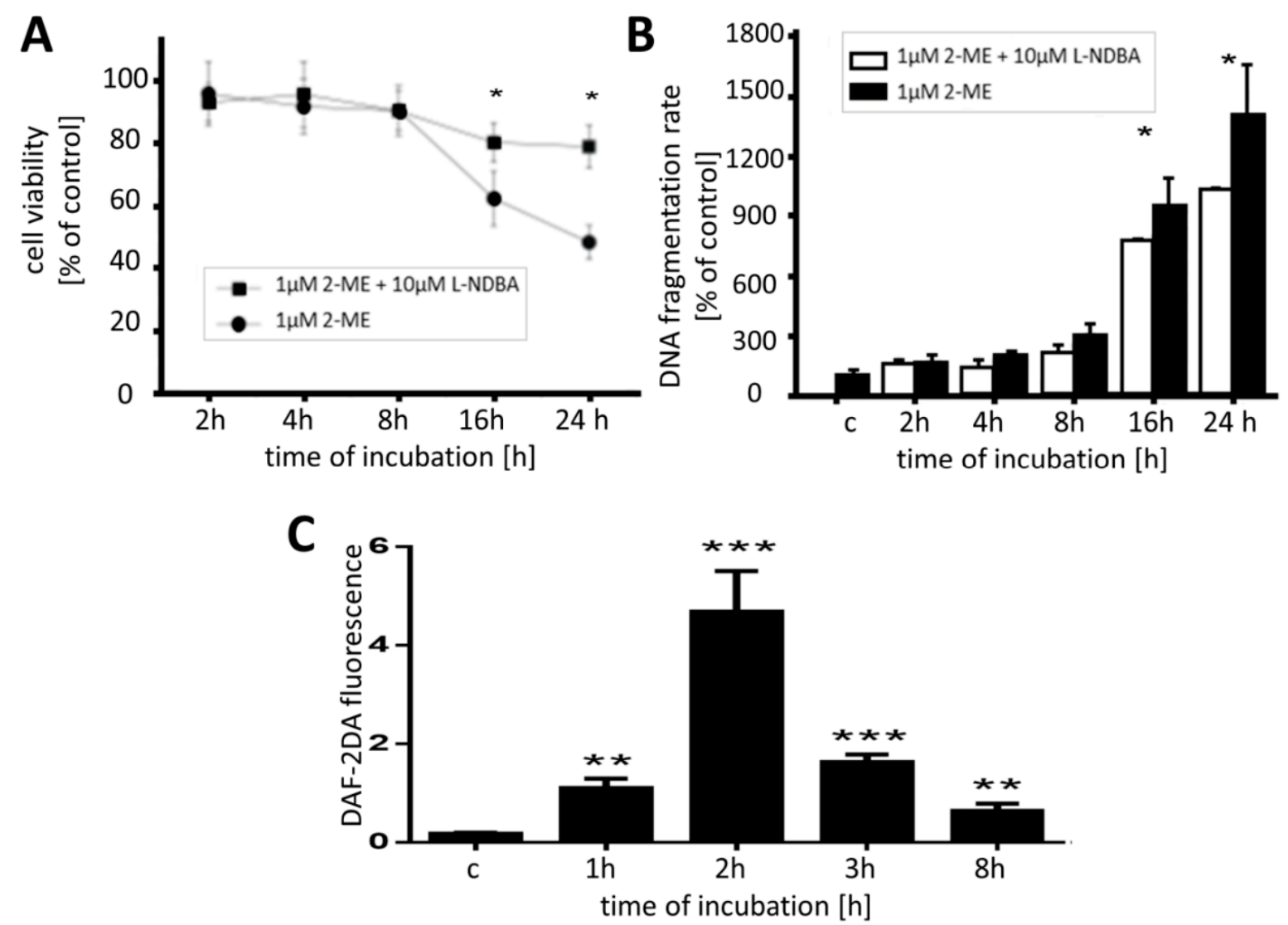

Data were analyzed performing the Student's $t$-test, if allowed by distribution, and presented as mean values $\pm \mathrm{SD}$ from three independent experiments, each performed in triplicate. ${ }^{*} p<0.05$, $* * p<0.01, * * * p<0.001$ versus control (c). 


\subsection{RNS Engaged in Anticancer Mechanism of 2-ME}

Impact on Level of Nitric Oxide

Enhanced activity of nNOS induced by 2-ME in 143B cells was confirmed by means of flow cytometry and a specific fluorescent detector-DAF-2DA-by the augmented levels of nitric oxide after incubation with stimuli. Generation of nitric oxide in 143B OS cells appeared to be dependent on time of incubation. Intracellular nitric oxide was increased 6-fold after $1 \mathrm{~h}$ incubation with1 $\mu \mathrm{M} \mathrm{2-ME}$ as compared to control $(\mathrm{c})(1 \mathrm{~h} ; 1.1 \pm 0.2$ versus control; $0.17 \pm 0.03)$ (Figure $5 \mathrm{C})$. The highest level of nitric oxide formation was observed after $2 \mathrm{~h}$ incubation with $1 \mu \mathrm{M} 2-\mathrm{ME}(2 \mathrm{~h} ; 4.68 \pm 0.83$ versus control; $0.17 \pm 0.03$ ). After $2 \mathrm{~h}$ of incubation the level of intracellular nitric oxide was dramatically decreased. Nonetheless at each time point beyond $4 \mathrm{~h}$ a significant generation of nitric oxide after treatment with $1 \mu \mathrm{M}$ 2-ME was detected as compared to control (c) (Figure 5C). 2-ME-induced DNA-damage (Figure 4B) seems to be a result of nitric oxide generation in OS cells. The association between upregulation of nitric oxide synthase in neurodegeneration disease has been previously described [41-47]. It has been recently reported that apoptosis of cerebellar granule neurons is triggered by the lowering of extracellular potassium levels and is dependent on both nNOS induction and a subsequent nitric oxide overproduction [47]. Moreover, the possible link between $\mathrm{CB}(2)$ receptors, nitric oxide synthases, nitro-oxidative stress, and cell death during neurodegeneration was reported by Pacher and Mackie [45]. While exogenous nitric oxide can induce apoptosis, it remains unclear if endogenously produced nitric oxide plays an important signaling role in cells undergoing apoptosis in response to various physiological stimuli [47]. Adjuvant role of RNS in anticancer therapy due to cancer cells chemosensitization has been widely reported [48]. One of the mechanisms of the pathogenic role of nitric oxide is its reaction with superoxide anion leading to peroxynitrite and consequently, nitrogen dioxide formation. Superoxide dismutase (SOD) competes with nitric oxide prevents generation of derivatives of nitric oxide (peroxynitrite, nitrogen dioxide) that may modify proteins to form 3-NT. Indeed, free 3-NT and similarly modified proteins are footprints of nitro-oxidative stress under pathophysiological conditions. It has been also revealed that nNOS plays an important role in nitration and thus inactivation of SOD in CNS [49].

Here, we demonstrated the common feature of neuronal and 2-ME-treated OS cells that is elevated level of 3-NT. The obtained data of increased nNOS induced by 2-ME in OS cells are strictly correlated to elevated 3-NT expression. The level of 3-NT was enhanced by approx. 2-fold as soon as after $2 \mathrm{~h}$ and maintained till $8 \mathrm{~h}$ of incubation with stimuli (Figure 3E,F). As demonstrated in Figure 2E,F HT22 are characterized by high level of 3-NT (approx. 5-fold higher as compared to OS 143B cells) plausibly due to constitutive nNOS expression. We observed nitric oxide production followed by cell death of 2-ME treated OS cells possibly associated with nitric oxide-DNA damage and elevated level of 3-NT. One of the proteins that may play an important role in neurodegenerative diseases development and tumor growth regulation is $\alpha$-synuclein, additionally involved in OS differentiation [25]. Nitrated $\alpha$-synuclein was reported to form brain lesions, a hallmark of neurodegenerative disorders, and the impact of nitrated $\alpha$-synuclein in OS cells in currently under our investigation. Nonetheless, Fuhjita and co-workers revealed its inhibitory influence on proteasome activity, alterations in protein kinase $\mathrm{C}$ signaling pathway and an autophagy lysosomal degradation system resulting in OS MG63 
differentiation [23]. Thus, it suggests that tumor growth and differentiation may overlap with neurological system.

\section{Experimental Section}

\subsection{Reagents}

Tissue culture media, antibiotic cocktail, foetal bovine serum, 2-methoxyestradiol, the nNOS inhibitor $N^{\omega}$-Nitroarginine-2,4-L-diaminobutyric amide di(trifluoroacetate) salt (L-NDBA) were purchased from Sigma-Aldrich (Poznan, Poland). Diaminofluorescein-FM diacetate (DAF-FM DA) and peroxidase-labeled rabbit anti-mouse IgG antibodies were obtained from Molecular Probes (Warsaw, Poland). Monoclonal antibodies against nNOS isoforms were obtained from BD Biosciences (Warsaw, Poland). Horseradish peroxidase-conjugated antibodies against beta-actin were purchased from Santa Cruz Biotechnology (Heidelberg, Germany).

\subsection{Cell Line and Culture Conditions}

The human highly metastatic OS 143B cell line (ATTC-8303) was obtained from the American Tissue Type Collection (Lomianki, Poland). Immortalized mouse hippocampal HT22 cell line was kindly gifted by Tilman Grune from Institute of Nutrition, Department of Nutritional Toxicology, Friedrich Schiller University (Jena, Germany) and by Kelvin Davies from University of Southern California (USC, Los Angeles, CA, USA). The cells were cultured at $37{ }^{\circ} \mathrm{C}$ in a humidified atmosphere saturated with $5 \% \mathrm{CO}_{2}$ using Dulbecco's Modified Eagle's medium supplemented with $10 \%$ heat-inactivated fetal bovine serum and a penicillin $(100 \mathrm{mg} / \mathrm{mL}) /$ streptomycin $(100 \mathrm{mg} / \mathrm{mL})$ cocktail (Sigma-Aldrich).

\subsection{Cell Viability Assay (MTT Assay)}

OS 143B cells were treated with serial 2-ME dilutions (within the range of $0.8-50 \mu \mathrm{M}$ ) of 2-ME for $24 \mathrm{~h}$. The MTT assay was performed as previously described [50]. The results were presented as a percentage of control (c). Each experiment was performed at least three times.

\subsection{Assessment of Apoptosis by Flow Cytometry with Double Annexin V-Propidium Iodide (PI) Staining}

OS 143B cells were seeded onto six-well plates at a density of three hundred thousand cells/well. After $24 \mathrm{~h}$ of culturing in the standard medium, the cells were treated with 2-ME for $24 \mathrm{~h}$. The annexin $\mathrm{V}$ - Pi staining was performed as previously described [50]. The results were then analyzed by the Cyflogic software, version 1.2.1. Each experiment was performed at least three times.

\subsection{Assessment of Apoptosis by DNA Fragmentation ELISA Kit}

Cell lysates were prepared from OS 143B cells treated with of $1 \mu \mathrm{M}$ 2-ME or pretreated for $2 \mathrm{~h}$ with $10 \mu \mathrm{M}$ L-NDBA and treated with $1 \mu \mathrm{M}$ 2-ME for $2 \mathrm{~h}$ up to $24 \mathrm{~h}$. Analysis of apoptosis was performed using a Cell Death Detection ELISA ${ }^{\text {PLUS }}$ kit (Roche, (San Francisco, CA, USA)) according to the manufacturer's protocol. 


\subsection{Western Blotting}

Equal amounts of total cell lysates were resolved by 7\% (nNOS) and 10\% (3-NT) SDS-PAGE. The membranes were then incubated with primary antibodies anti-nNOS (BD Biosciences) (1:1000), anti-3-NT (Sigma-Aldrich) $(1: 10,000)$ overnight at $4{ }^{\circ} \mathrm{C}$ and next, analysis performed as previously described [50]. The protein level was quantified by densitometry technique using the Quantity one 4.5.2 software. The protein levels, as determined by chemiluminescent quantification, were normalized relative to beta-actin levels found in the samples. Each experiment was performed at least three times.

\subsection{Immunofluorescence Microscopy}

The immunofluorescense was performed as previously described [50]. The cells were treated with 2-ME for $8 \mathrm{~h}$. Anti-eNOS, anti-iNOS (1:50 in 0.3\% GSA, $2 \mathrm{~h}$ incubation, BD Biosciences) and goat anti mouse secondary-conjugated with CY3 (1:100, GAM Cy3, 1 h incubation, Jackson Immunoresearch, Suffolk, UK) antibodies were used. The images were analysed and merged employing the ImageJ software 1.44 p. Each experiment was performed at least three times.

\subsection{Statistical Analysis}

Data are presented as the mean $\pm \mathrm{SE}$ values form at least three independent experiments. Data were analysed using GraphPad Prism (GraphPad Software, Inc., version 6.03, La Jolla, CA, USA). Significant differences between groups were determined by One-way ANOVA combined with Dunett's Multiple Comparison test or Student's $t$-test.

\section{Conclusions}

Though the mechanisms of 2-ME action is still undefined, the drug is currently under clinical trials as a chemotherapeutic agent [8-11]. Herein, we presented data suggesting that 2-ME when used at pharmacological concentrations acts as effective anticancer agent, but also as plausible neurotoxin towards hippocampal HT22 cells. Thus, we hypothesize plausible side effects of chemotherapy with 2-ME like memory disorders or depression associated with loss of hippocampal cells.

\section{Acknowledgments}

The project was funded by grant No. 2012/07/B/NZ1/00010 from National Science Center resources. M.W. acknowledges support from Medical University of Gdansk Funding No. ST46. We thank Agnieszka Daca and Jacek Witkowski for their help in flow-cytometric analyses. We thank Antonella Marino Gammazza and Francesco Cappello for their help in immunofluorescence analyses of NOSs. The funders had no role in study design, data collect ion and analysis, decision to publish, or preparation of the manuscript.

\section{Author Contributions}

Conceived and designed the experiments: Magdalena Gorska and Michal Wozniak. Performed the experiments: Magdalena Gorska, Alicja Kuban-Jankowska, Monika Gorzynik and Michal Szkatula. 
Analyzed the data: Magdalena Gorska, Michal Aleksander Zmijewski and Michal Wozniak. Manuscript corrections Magdalena Gorska, Michal Aleksander Zmijewski and Michal Wozniak Wrote the paper: Magdalena Gorska.

\section{Abbreviation}

c: Control; CNS: Central nervous system; DAF-2DA: Diaminofluorescein-2-diacetate; E2: $17 \beta$-Estradiol; L-NDBA: $N^{\omega}$-Nitroarginine-2,4-L-diaminobutyric amide di(trifluoroacetate) salt; 2-ME: 2-Methoxyestradiol; nNOS: Neuronal nitric oxide synthase; 3-NT: 3-Nitrotyrosine; NMDA: N-Methyl-D-aspartate receptor; OS: Osteosarcoma; PD: Parkinson's disease; SOD: Superoxide dismutase.

\section{Conflicts of Interest}

The authors declare no conflict of interest.

\section{References}

1. Lethaby, C.D. A systematic review of time to diagnosis in children and young adults with cancer. Arch. Dis. Child. 2013, 98, 349-355.

2. Chi, S.N.; Conklin, L.S.; Qin, J.; Meyers, P.A.; Huvos, A.G.; Healey, J.H.; Gorlick, R. The patterns of relapse in osteosarcoma: The memorial sloan-kettering experience. Pediatr. Blood Cancer 2004, 42, 46-51.

3. Van Driel, M.; van Leeuwen, J.P. Cancer and bone: A complex. Arch. Biochem. Biophys. 2014, 18, doi:10.1016/j.abb.2014.07.013.

4. Luetke, A.; Meyers, P.A.; Lewis, I.; Juergens, H. Osteosarcoma treatment-Where do we stand? A state of the art review. Cancer Treat. Rev. 2014, 40, 523-532.

5. Yamamoto, N.; Tsuchiya, H. Chemotherapy for osteosarcoma-Where does it come from? What is it? Where is it going? Expert Opin. Pharmacother. 2013, 14, 2183-2193.

6. Yang, C.Y.; Chen, C.F.; Chen, W.M.; Wu, P.K.; Lee, F.T.; Chen, P.C.; Liu, C.L.; Chen, T.H. Osteoblastoma in the region of the hip. J. Chin. Med. Assoc. 2013, 76, 115-120.

7. Yuan, W.; Yu, Y.; Li, J.; Singh, P.; Li, D.; Gui, Y.; Zheng, X.L. Estrogen metabolite 2-methoxyestradiol prevents hypertension in deoxycorticosterone acetate-salt rats. Cardiovasc. Drugs Ther. 2013, 27, 17-22.

8. Peyrat, J.F.; Brion, J.-D.; Alami, M. Synthetic 2-methoxyestradiol derivatives: Structure-activity relationships. Curr. Med. Chem. 2012, 19, 4142-4156.

9. Bruce, J.Y.; Eickhoff, J.; Pili, R.; Logan, T.; Carducci, M.; Arnott, J.; Treston, A.; Wilding, G.; Liu, G. A phase II study of 2-methoxyestradiol nanocrystal colloidal dispersion alone and in combination with sunitinib malate in patients with metastatic renal cell carcinoma progressing on sunitinib malate. Investig. New Drugs 2012, 30, 794-802.

10. Kulke, M.H.; Chan, J.A.; Meyerhardt, J.A.; Zhu, A.X.; Abrams, T.A.; Blaszkowsky, L.S.; Regan, E.; Sidor, C.; Fuchs, C.S. A prospective phase II study of 2-methoxyestradiol administered in combination with bevacizumab in patients with metastatic carcinoid tumors. Cancer Chemother. Pharmacol. 2011, 68, 293-300. 
11. Harrison, M.R.; Hahn, N.M.; Pili, R.; Oh, W.K.; Hammers, H.; Sweeney, C.; Kim, K.; Perlman, S.; Arnott, J.; Sidor, C.; et al. A phase II study of 2-methoxyestradiol (2ME2), NanoCrystalA (R) dispersion (NCD) in patients with taxane-refractory metastatic castrate-resistant prostate cancer (CRPC). Investig. New Drugs 2011, 29, 1465-1474.

12. Duncan, G.S.; Brenner, D.; Tusche, M.W.; Brüstle, A.; Knobbe, C.B.; Elia, A.J.; Mock, T.; Bray, M.R.; Krammer, P.H.; Mak, T.W. 2-Methoxyestradiol inhibits experimental autoimmune encephalomyelitis through suppression of immune cell activation. Proc. Natl. Acad. Sci. USA 2012, 109, 21034-21039.

13. Benedikt, M.B.; Mahlum, E.W.; Shogren, K.L.; Subramaniam, M.; Spelsberg, T.C. 2-Methoxyestradiol regulates osteoprotegerin expression in osteosarcoma cells. J. Cell. Biochem. 2010, 109, 950-956.

14. Maran, A.; Shogren, K.L.; Benedikt, M.; Sarkar, G.; Turner, R.T.; Yaszemski, M.J. 2-Methoxyestradiol-induced cell death in osteosarcoma cells is preceded by cell cycle arrest. J. Cell. Biochem. 2008, 104, 1937-1945.

15. Maran, A.; Zhang, M.; Kennedy, A.M.; Sibonga, J.D.; Rickard, D.J.; Spelsberg, T.C.; Turner, R.T. 2-Methoxyestradiol induces interferon gene expression and apoptosis in osteosarcoma cells. Bone 2002, 30, 393-398.

16. Cicek, M.; Iwaniec, U.T.; Goblirsch, M.J.; Vrabel, A.; Ruan, M.; Clohisy, D.R.; Turner, R.R.; Oursler, M.J. 2-methoxyestradiol suppresses osteolytic breast cancer tumor progression in vivo. Cancer Res. 2007, 67, 10106-10111.

17. Rajkumar, S.V.; Richardson, P.G.; Lacy, M.Q.; Dispenzieri, A.; Greipp, P.R.; Witzig, T.E.; Schlossman, R.; Sidor, C.F.; Anderson, K.C.; Gertz, M.A. Novel therapy with 2-methoxyestradiol for the treatment of relapsed and plateau phase multiple myeloma. Clin. Cancer Res. 2007, 13, 6162-6167.

18. Dahut, W.L.; Lakhani, N.J.; Gulley, J.L.; Arlen, P.M.; Kohn, E.C.; Kotz, H.; McNally, D.; Parr, A.; Nguyen, D.; Yang, S.X.; et al. Phase I clinical trial of oral 2-methoxyestradiol, an antiangiogenic and apoptotic agent, in patients with solid tumors. Cancer Biol. Ther. 2006, 5, 22-27.

19. Sweeney, C.; Liu, G.; Yiannoutsos, C.; Kolesar, J.; Horvath, D.; Staab, M.J.; Fife, K.; Armstrong, V.; Treston, A.; Sidor, C.; et al. A phase II multicenter, randomized, double-blind, safety trial assessing the pharmacokinetics, pharmacodynamics, and efficacy of oral 2-methoxyestradiol capsules in hormone-refractory prostate cancer. Clin. Cancer Res. 2005, 11, 6625-6633.

20. Sutherland, T.E.; Anderson, R.L.; Hughes, R.A.; Altmann, E.; Schuliga, M.; Ziogas, J.; Stewart, A.G. 2-Methoxyestradiol-A unique blend of activities generating a new class of anti-tumour/anti-inflammatory agents. Drug Discov. Today 2007, 12, 577-584.

21. Mueck, A.O.; Seeger, H. 2-Methoxyestradiol-Biology and mechanism of action. Steroids 2010, 75, 625-631.

22. Seegers, J.C.; Lottering, M.L.; Grobler, C.J.; van Papendorp, D.H.; Habbersett, R.C.; Shou, Y.; Lehnert, B.E. The mammalian metabolite, 2-methoxyestradiol, affects p53 levels and apoptosis induction in transformed cells but not in normal cells. J. Steroid Biochem. Mol. Biol. 1997, 62, 253-267.

23. West, A.B.; Dawson, V.L.; Dawson, T.M. To die or grow: Parkinson's disease and cancer. Trends Neurosci. 2005, 28, 348-352. 
24. Picchio, M.C.; Martin, E.S.; Cesari, R.; Calin, G.A.; Yendamuri, S.; Kuroki, T.; Pentimalli, F.; Sarti, M.; Yoder, K.; Kaiser, L.R.; et al. Alterations of the tumor suppressor gene Parkin in non-small cell lung cancer. Clin. Cancer Res. 2004, 10, 2720-2724.

25. Giasson, B.I.; Duda, J.E.; Murray, I.V.J.; Chen, Q.P.; Souza, J.M.; Hurtig, H.I.; Ischiropoulos, H.; Trojanowski, J.Q.; Lee, V.M.Y. Oxidative damage linked to neurodegeneration by selective alpha-synuclein nitration in synucleinopathy lesions. Science 2000, 29, 985-989.

26. Fujita, M.; Sugama, S.; Nakai, M.; Takenouchi, T.; Wei, J.S.; Urano, T.; Inoue, S.; Hashimoto, M. Alpha-synuclein stimulates differentiation of osteosarcoma cells-Relevance to down-regulation of proteasome activity. J. Biol. Chem. 2007, 282, 5736-5748.

27. Foerstermann, U.; Sessa, C. Nitric oxide synthases: Regulation and function. Eur. Heart J. 2012, 33, 829-837.

28. Ischiropoulos, H. Biological tyrosine nitration: A pathophysiological function of nitric oxide and reactive oxygen species. Arch. Biochem. Biophys. 1998, 356, 1-11.

29. Ischiropoulos, H.; Beckman, J.S. Oxidative stress and nitration in neurodegeneration: Cause, effect, or association? J. Clin. Investig. 2003, 111, 163-169.

30. Blanchard-Fillion, B.; Prou, D.; Polydoro, M.; Spielberg, D.; Tsika, E.; Wang, Z.N.; Hazen, S.L.; Koval, M.; Przedborski, S.; Ischiropoulos, H. Metabolism of 3-nitrotyrosine induces apoptotic death in dopaminergic cells. J. Neurosci. 2006, 26, 6124-6130.

31. Mihm, M.J.; Schanbacher, B.L.; Wallace, B.L.; Wallace, J.L.; Uretsky, N.J.; Bauer, J.A. Free 3-nitrotyrosine causes striatal neurodegeneration in vivo. J. Neurosci. 2001, 21, RC149.

32. Kalariti, N.; Lembessis, P.; Koutsilieris, M. Characterization of the glutametergic system in MG-63 osteoblast-like osteosarcoma cells. Anticancer Res. 2004, 24, 3923-3929.

33. Skerry, T.M.; Genever, P.G. Glutamate signalling in non-neuronal tissues. Trends Pharmacol. Sci. 2001, 22, 174-181.

34. Tofighi, R.; Johansson, C.; Goldoni, M.; Ibrahim, W.N.; Gogvadze, V.; Mutti, A.; Ceccatelli, S. Hippocampal neurons exposed to the environmental contaminants methylmercury and polychlorinated biphenyls undergo cell death via parallel activation of calpains and lysosomal proteases. Neurotox. Res. 2011, 19, 183-194.

35. Liua, J.; Lib, L.; Suob, W.Z. HT22 hippocampal neuronal cell line possesses functional cholinergic properties. Life Sci. 2009, 27, 267-271.

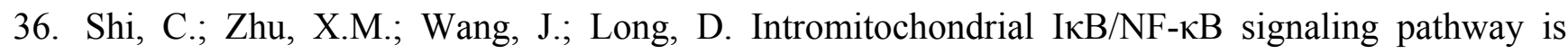
involved in amyloid $\beta$ peptide-induced mitochondrial dysfunction. J. Bioenerg. Biomembr. 2014, doi:10.1007/s10863-014-9567-7.

37. Siedlecka-Kroplewska, K.; Szczerba, A.; Lipinska, A.; Slebioda, T.; Kmiec, Z. 3-Fluoromethcathinone, a structural analog of mephedrone, inhibits growth and induces cell cycle arrest in HT22 mouse hippocampal cells. J. Physiol. Pharmacol. 2014, 65, 241-246.

38. Picazo, O.; Azcoitia, I.; Garcia-Segura, L.M. Neuroprotective and neurotoxic effects of estrogens. Brain Res. 2003, 990, 20-27.

39. Alderton, W.K.; Cooper, C.E.; Knowles, R.G. Nitric oxide synthases: Structure, function and inhibition. Biochem. J. 2001, 357, 593-615. 
40. Tsukamoto, A.; Kaneko, Y.; Yoshida, T.; Han, K.; Ichinose, M.; Kimura, S. 2-Methoxyestradiol, an endogenous metabolite of estrogen, enhances apoptosis and beta-galactosidase expression in vascular endothelial cells. Biochem. Biophys. Res. Commun. 1998, 248, 9-12.

41. Yeo, W.S.; Kim, Y.J.; Kabir, M.H.; Kang, J.W.; Kim, K.P. Mass spectrometric analysis of protein tyrosine nitration in aging and neurodegenerative diseases. Mass Spectrom. Rev. 2014, 2 , doi:10.1002/mas.21429.

42. Feeney, M.B.; Schöneich, C. Tyrosine modifications in aging. Antioxid. Redox Signal. 2012, 17, 1571-1579.

43. Bombeiro, A.L.; D’Império Lima, M.R.; Chadi, G.; Alvarez, J.M. Neurodegeneration and increased production of nitrotyrosine, nitric oxide synthase, IFN-gamma and S100beta protein in the spinal cord of IL-12p40-deficient mice infected with Trypanosoma cruzi. Neuroimmunomodulation 2010, 17, 67-78.

44. Bitel, C.L.; Feng, Y.; Souayah, N.; Frederikse, P.H. Increased expression and local accumulation of the prion protein, Alzheimer $A \beta$ peptides, superoxide dismutase 1, and nitric oxide synthases $1 \& 2$ in muscle in a rabbit model of diabetes. BMC Physiol. 2010, 10, 18.

45. Pacher, P.; Mackie, K. Interplay of cannabinoid 2 (CB2) receptors with nitric oxide synthases, oxidative and nitrative stress, and cell death during remote neurodegeneration. J. Mol. Med. 2012, 90, 347-351.

46. Bobba, A.; Atlante, A.; Moro, L.; Calissano, P.; Marra, E. Nitric oxide has dual opposite roles during early and late phases of apoptosis in cerebellar granule neurons. Apoptosis 2007, 12, 1597-1610.

47. Heigold, S.; Sers, C.; Bechtel, W.; Ivanovas, B.; Schafer, R.; Bauer, G. Nitric oxide mediates apoptosis induction selectively in transformed fibroblasts compared to nontransformed fibroblasts. Carcinogenesis 2002, 23, 929-941.

48. Sullivan, R.; Graham, C.H. Chemosensitization of cancer by nitric oxide. Curr. Pharm. Des. 2008, 14, 1113-1123.

49. Bayir, H.; Kagan, C.E.; Clark, R.S.B.; Janesko-Feldman, K.; Rafikov, R.; Huang, Z.T.; Zhang, X.J.; Vagni, V.; Billiar, T.R.; Kochanek, P.M. Neuronal NOS-mediated nitration and inactivation of manganese superoxide dismutase in brain after experimental and human brain injury. J. Neurochem. 2007, 101, 168-181.

50. Gorska, M.; Gammazza, A.M.; Zmijewski, M.A.; Campanella, C.; Cappello, F.; Wasiewicz, T.; Kuban-Jankowska, A.; Daca, A.; Sielicka, A.; Popowska, U.; et al. Geldanamycin-induced osteosarcoma cell death is associated with hyperacetylation and loss of mitochondrial pool of heat shock protein 60 (Hsp60). PLoS One 2013, 8, e71135.

Sample Availability: Samples of the compounds (2-ME) are available from the authors.

(C) 2014 by the authors; licensee MDPI, Basel, Switzerland. This article is an open access article distributed under the terms and conditions of the Creative Commons Attribution license (http://creativecommons.org/licenses/by/3.0/). 